\title{
Archivi e archivisti in Italia tra medioevo ed età moderna. Filippo de Vivo, Andrea Guidi, and Alessandro Silvestri, eds. I libri di Viella 203. Rome: Viella, 2015. 396 pp. $€ 36$.
}

Historians are aware of the importance of the Italian archives because of the quantity and quality of documents these institutions preserve. Archives, however, can also be studied as historical sources in themselves because the whole process of producing, arranging, and preserving documents reveals how institutions have been created and how societies have built their own identity. Order and disorder within archives can be interpreted as a result of the good or bad organization of offices, of a period of stability or of change. The history of the people in charge of record-keeping (from notaries to chancery officials to archivists) also tells us about the institutions they worked in and which they have contributed to shape.

A comparative history of archives in late medieval and early modern Italy was the field of research of the ERC project AR.C.H.I.ves (http://www.bbk.ac.uk/history/ archives/), which promoted this volume-it was led by Filippo de Vivo at the University of London, with Andrea Guidi and Alessandro Silvestri on the research team. The project focused on the archives of seven leading Italian cities: Milan, Venice, Modena, Florence, Rome, Naples, and Palermo. This book gathers together a number of additional case studies, which have been arranged in three sections according to the perspective from which each case is examined. Broadly, these sections correspond to the following social, political, and cultural history approaches: "Individuals and Collective Strategies," "Archives and Power," and "Archives and Culture." The case studies focusing on individuals come with an analysis of entire social groups. For example, in the first section, the history of individual officials, such as Luca Beni della Serra (Piergentili) and the chancellor of the legate of Bologna (Gardi), is followed by an in-depth social analysis of the secretaries and chancery officials of the Republic of Genoa between the fifteenth and eighteenth centuries (Bitossi). The second section is opened and closed by two essays providing a wider view: Filippo de Vivo shows how the perception of the centrality of the republic's 
archives for the Venetian governments (they were regarded as the "heart of the state") was the result of continuing, day to day, struggles over a period of three centuries. Andrea Giorgi and Stefano Moscadelli present a substantial analysis of the policies implemented in the organization of notarial archives across the country over a long period of time. This investigation leads them to reaffirm the stability and importance of the role played by notaries in public administration throughout early modern Italy.

The final section of the volume shows the different ways by which officials in charge of documents pursued parallel cultural activities. An example is the notary of the Duke of Ferrara, Ugo Caleffini, who wrote a history of the town (Saletti). Giacomo Giudici focuses on the importance of Ludovico Annibale Della Croce's experience, as a humanist and man of letters, in working as secretary of the Duchy of Milan. Of great interest is the account of the development of a notarial culture, as shown in a treatise written around 1460 by Pietro Della Valle, who aimed to provide practical information on documents and procedures (De arte cancellarie). Gian Maria Varanini shows the context in which Della Valle's work was written and how it reflected the Venetian government's reinforcement of control over its territories. The final essay in the third section by Peter Burke also concludes the volume as a "postfazione." He offers general considerations on the discipline under the title Cos"e la storia degli archivi: what is the history of archives? That echoes Burke's renowned question, "what is cultural history?" Burke stresses the revolutionary effects of studying the history of archives, a study that can lead to the need to revise traditional periodizations and to create new interpretive paradigms.

As in any collection of essays, this volume can be read at various levels. Each case study is rich in information, but some essays stress the methodology and the general conceptual framework of the volume as a whole better than others. Particularly interesting from this point of view is the introduction, in which readers will find a comprehensive, detailed, and penetrating reconstruction of the development of the historiographical trends over recent decades, which underlie the research project that promoted this volume.

Maria Alessandra Panzanelli Fratoni, University of Oxford 